Revue bibliographique pour le domaine irano-aryen

\title{
Sépideh Qahéri. « Fragments de vaisselle inscrite en égyptien conservés au Musée National d'Iran (Irān-e-Bāstān) - Téhéran »
}

\section{Astrid Nunn}

\section{(2) OpenEdition}

Journals

Édition électronique

URL : http://journals.openedition.org/abstractairanica/42797

DOI : 10.4000/abstractairanica.42797

ISSN : 1961-960X

Éditeur :

CNRS (UMR 7528 Mondes iraniens et indiens), Éditions de l'IFRI

Référence électronique

Astrid Nunn, « Sépideh Qahéri. «Fragments de vaisselle inscrite en égyptien conservés au Musée National d'Iran (Irān-e-Bāstān) - Téhéran » », Abstracta Iranica [En ligne], Volume 34-35-36 | 2017, document 126, mis en ligne le 30 juillet 2017, consulté le 05 octobre 2020. URL : http:// journals.openedition.org/abstractairanica/42797; DOI : https://doi.org/10.4000/abstractairanica. 42797

Ce document a été généré automatiquement le 5 octobre 2020.

Tous droits réservés 


\title{
Sépideh Qahéri. « Fragments de vaisselle inscrite en égyptien conservés au Musée National d'Iran (Irān-e-Bāstān) - Téhéran »
}

\author{
Astrid Nunn
}

\section{RÉFÉRENCE}

Sépideh Qahéri. « Fragments de vaisselle inscrite en égyptien conservés au Musée National d'Iran (Irān-e-Bāstān) - Téhéran », BIFAO 112, 2012, p. 317-348.

1 De Suse et Persépolis provient de la vaisselle en pierre et d'origine égyptienne sur laquelle les titulatures des rois achéménides Darius I, Xerxès et Artaxerxès ont été gravées en cunéiforme et en hiéroglyphique. L'A se penche ici sur les récipients à inscription hiéroglyphique et conservés au MNI, qui, sauf un, proviennent de Persépolis. Une coupe et un fragment de lotus, tous deux en albâtre, remontent aux rois saïtes Néchao II et Amasis. Huit fragments en albâtre ou en roche dure foncée de jarres, d'alabastra, de coupes et de plateaux datent de Xerxès I, deux nomment Artaxerxès. Les noms écrits en hiéroglyphes sont parfois suivis d'une titulature. Trois fragments ne peuvent être attribués. Ces vases retrouvés dans la Trésorerie de Persépolis étaient soit un butin de guerre récupéré par les Achéménides, soit acquis, soit des cadeaux. Il reste néanmoins possible que la vaisselle de table ait été fabriquée en Perse avec des matériaux égyptiens. 


\section{AUTEURS}

\section{ASTRID NUNN}

Université de Munich 